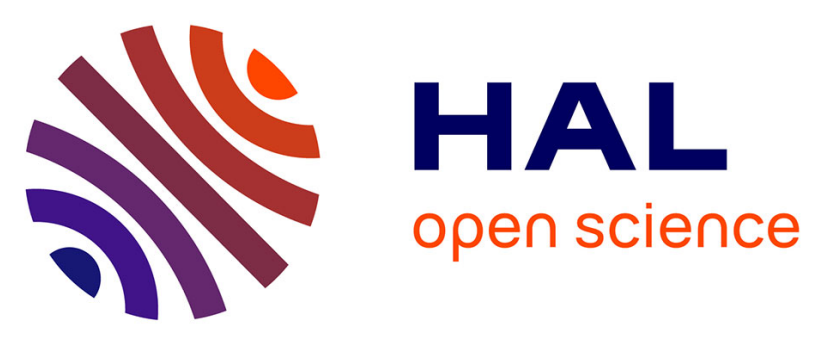

\title{
Proteome changes during pork meat ageing following use of two different pre-slaughter handling procedures
}

Martine Morzel, Christophe Chambon, Muriel Hamelin, Veronique

Sante-Lhoutellier, Thierry Sayd, Gabriel Monin

\section{- To cite this version:}

Martine Morzel, Christophe Chambon, Muriel Hamelin, Veronique Sante-Lhoutellier, Thierry Sayd, et al.. Proteome changes during pork meat ageing following use of two different pre-slaughter handling procedures. Meat Science, 2004, 67 (4), pp.689-696. 10.1016/j.meatsci.2004.01.008 . hal-02871098

\section{HAL Id: hal-02871098 \\ https://hal.inrae.fr/hal-02871098}

Submitted on 17 Jun 2020

HAL is a multi-disciplinary open access archive for the deposit and dissemination of scientific research documents, whether they are published or not. The documents may come from teaching and research institutions in France or abroad, or from public or private research centers.
L'archive ouverte pluridisciplinaire HAL, est destinée au dépôt et à la diffusion de documents scientifiques de niveau recherche, publiés ou non, émanant des établissements d'enseignement et de recherche français ou étrangers, des laboratoires publics ou privés.

\section{(1) (1) $\$$}

Distributed under a Creative Commons Attribution - NonCommercial - NoDerivatives 44.0 


\title{
Proteome changes during pork meat ageing following use of two different pre-slaughter handling procedures
}

\author{
Martine Morzel ${ }^{\mathrm{a}, *}$, Christophe Chambon ${ }^{\mathrm{b}}$, Muriel Hamelin ${ }^{\mathrm{a}}$, \\ Véronique Santé-Lhoutellier ${ }^{a}$, Thierry Sayd ${ }^{\mathrm{a}}$, Gabriel Monin ${ }^{\mathrm{a}}$ \\ ${ }^{a}$ Biochimie et Physiologie du Muscle, Station de Recherches sur la Viande, INRA, 63122 St Genès-Champanelle, France \\ ${ }^{\mathrm{b}}$ Plateforme Protéomique, Station de Recherches sur la Viande, INRA, 63122 St Genès-Champanelle, France
}

Received 26 November 2003; received in revised form 20 January 2004; accepted 26 January 2004

\begin{abstract}
The influence of postmortem storage time and pre-slaughter conditions (transport the day before slaughter or immediately before slaughter) on proteome changes of pork meat was investigated over a $72 \mathrm{~h}$ ageing period. Intensities of 37 spots varied significantly $(p<0.05)$ with ageing time. Changes indicated proteolysis of troponin T, actin, $\alpha$-crystallin, myokinase, creatine kinase and mitochondrial ATPase, but also of proteins constitutive of the Z-lines, namely cypher proteins and myozenin. Other modifications were the intensity increase of a full-length protein of the sarcoplasmic reticulum, which may be linked to its increased extractibility after membrane disruption, and a gradual shift in pHi towards alkaline values of some forms of myosin light chains (MLC) 2 and 3. The pre-slaughter conditions affected significantly $(p<0.05) 8$ spots. Mitochondrial ATPase was over-expressed in the group transported immediately before slaughter, also characterised by a faster $\mathrm{pH}$ fall, and the shift in pHi of MLC 2 was more pronounced. The pre-slaughter conditions had no significant effect on the above proteolytic events.
\end{abstract}

(C) 2004 Elsevier Ltd. All rights reserved.

Keywords: Pork; Meat ageing; Proteomics; 2D electrophoresis; Rate of $\mathrm{pH}$ decline

\section{Introduction}

Because muscle is composed almost exclusively of water and proteins, meat and seafood science cannot be dissociated from the study of structural or functional proteins, either in vivo or postmortem. For that purpose, the most common separating techniques are 1-D electrophoresis and chromatographic techniques. 2-D electrophoresis is gaining interest since it allows the concomitant separation of hundreds or even thousands of proteins. The number of applications related to postmortem study of meat and muscle foods has been somewhat limited. Thus, 2-D electrophoresis was used to characterise phenomena occurring during meat ageing and fish cold storage (Kjaesgård \& Jessen, 2003; Lame-

\footnotetext{
${ }^{*}$ Corresponding author. Fax: +-33-473-62-4268.

E-mail address: morzel@clermont.inra.fr (M. Morzel).
}

tsch \& Bendixen, 2001; Lametsch et al., 2003; Lametsch, Roepstorff, \& Bendixen, 2002; Verrez-Bagnis, Ladrat, Morzel, Noël, \& Fleurence, 2001) or during processing of fish products (Martinez, Solberg, Lauritzen, \& Ofstad, 1992; Morzel, Verrez-Bagnis, Arendt, \& Fleurence, 2000). However, the most recent study (Lametsch et al., 2003) showed that it was possible to correlate proteome changes and tenderness of meat. In this context, proteomics appears as a promising technique to establish the link between protein changes occurring postmortem and sensory or technological characteristics of meat. Preslaughter conditions including lairage time are known to influence pork quality through a variety of incidences such as muscle temperature, glycogen depletion, rate of pH decline. (e.g., Dall Aaslyng \& Barton Gade, 2000). With the objective of unveiling mechanisms by which pre-slaughter conditions influence ageing, postmortem proteome changes were studied in pork meat from animals slaughtered in two conditions. 


\section{Materials and methods}

\subsection{Animals and samples}

The animals used in this study were six Large White pigs, all slaughtered in the same commercial abattoir. Three pigs were slaughtered under commercial conditions (mixing of animals from different pens and transport to the abattoir $12 \mathrm{~h}$ before slaughter), and three were slaughtered under experimental conditions (no mixing of animals, transport immediately before slaughter). Samples were excised with a corer from the Longissimus lumborum (LL) at the last rib immediately after dehairing. Such samples corresponded to time $0 \mathrm{~h}$. The LL was removed from the carcass at $2 \mathrm{~h}$ postmortem and stored at $4{ }^{\circ} \mathrm{C}$. At $12 \mathrm{~h}$ postmortem, samples of approximately $5 \mathrm{~g}$ were sampled at the same level as the previously cored samples. A $4 \mathrm{~cm}$ LL slice was excised $24 \mathrm{~h}$ after slaughter, from the last rib towards the ham. The slice was vacuumpacked and stored at $4{ }^{\circ} \mathrm{C}$. Samples of approximately $5 \mathrm{~g}$ were taken from that slice at $72 \mathrm{~h}$ postmortem. All samples were frozen in liquid nitrogen and stored at $-80{ }^{\circ} \mathrm{C}$ until used.

\section{2. $p H$ measurement}

$\mathrm{pH}$ was measured at 45 min postmortem: approximately $2 \mathrm{~g}$ of LL muscle, taken at the last rib, were homogenised in $18 \mathrm{ml}$ of $0.005 \mathrm{M}$ iodoacetate and readings were taken using a $\mathrm{pH}$ meter CG822 (SchottGeräte, Hofheim, Germany). The ultimate $\mathrm{pH}$ was recorded on the day after slaughter: readings were taken in duplicate directly in the LL, from the $4 \mathrm{~cm}$ slice described above, using a PH62 spear probe meter (WTW, Weilheim, Germany).

\subsection{Protein extraction}

The extraction buffer consisted of $7 \mathrm{M}$ urea, $2 \mathrm{M}$ thiourea, $1 \%(\mathrm{w} / \mathrm{v})$ DTT, 2\% (w/v) CHAPS, $40 \mathrm{mM}$ Tris, $5 \mathrm{mM}$ Pefabloc, $1 \mathrm{mM}$ EDTA and $0.8 \%$ carrier ampholytes. $50 \mathrm{mg}$ of muscle were added to $1 \mathrm{ml}$ of extraction buffer in an Eppendorf containing a glass bead. Homogenisation was performed in Retsch MM2 agitator (Retsch, Haan, Germany) for $1 \mathrm{~h}$ at $4{ }^{\circ} \mathrm{C}$. Extracts were centrifuged at $10,000 \mathrm{~g}$ for $1 \mathrm{~h}$ at $10^{\circ} \mathrm{C}$ and the supernatant was collected. The protein content was measured using a Bio-Rad RC DC protein assay kit.

\subsection{2-D electrophoresis}

Immobilised $\mathrm{pH}$ gradient (IPG) isoelectric focusing (IEF) was carried out in a Protean IEF cell (Bio-Rad), using Bio-Rad ReadyStrip, $17 \mathrm{~cm}$, pH 3-10 non-linear. 90 or $1000 \mu \mathrm{g}$ of protein were loaded onto the strips for analytical or preparative gels, respectively. Proteins were loaded by inclusion of an adequate volume of extract in a buffer consisting of $7 \mathrm{M}$ urea, $2 \mathrm{M}$ thiourea, $2 \%(\mathrm{w} / \mathrm{v})$ CHAPS, $5 \mathrm{Mm}$ Pefabloc, $0.2 \%$ (w/v) DTT and $0.2 \%$ carrier ampholytes. Strips were rehydrated overnight. For the subsequent IEF, voltage was increased gradually to $10,000 \mathrm{~V}$ until a total of $60,000 \mathrm{Vh}$. Strips were immediately frozen and stored at $-20{ }^{\circ} \mathrm{C}$ until further use.

Prior to SDS-PAGE, strips were equilibrated for $15 \mathrm{~min}$ followed by $25 \mathrm{~min}$ in a solution of $6 \mathrm{M}$ urea, $30 \%(\mathrm{v} / \mathrm{v})$ glycerol, $2 \%(\mathrm{w} / \mathrm{v})$ SDS and $50 \mathrm{mM}$ Tris, supplemented successively with $1 \%(\mathrm{w} / \mathrm{v})$ DTT or $2.5 \%$ $(\mathrm{w} / \mathrm{v})$ iodoacetamide and bromophenol blue as a dye. SDS-PAGE was performed in a protean IIxi cell (BioRad) on $11 \%$ polyacrylamide gels at $15 \mathrm{~mA}$, until the dye track reached the end of the gels. Analytical gels were silver stained following the protocol of Yan et al. (2000). Preparative gels were stained in $0.02 \%$ colloidal Coomassie blue and destained in water. Gels were produced in triplicate and the two gels of best quality were retained for further analysis.

\subsection{Image analysis}

Gels images were acquired through a GS-800 densitometer and analysed using the PDQuest software (BioRad). After automated detection and matching, highly saturated or ill-defined spots were manually removed and matching across gels was inspected and corrected when necessary. The statistical effects of postmortem storage and initial $\mathrm{pH}$ on spot quantities were tested for significance at the 5\% level by two-way ANOVA using the GLM procedure of SAS v8.10 (SAS Institute Inc., Cary, USA).

\subsection{In-gel digestion of protein spots, desalting, concen- tration and identification}

Spots were excised from preparative gels using pipette tips. Gel pieces were placed into 96-wells plates, destained, digested and desalted using the Montage In-Gel

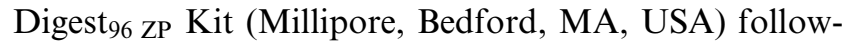
ing the supplier's instructions. Resulting peptides mixtures were loaded directly onto the MALDI target. The matrix solution ( $5 \mathrm{mg} \mathrm{ml}^{-1} \alpha$-cyano-4-hydroxycinnamic acid in $50 \%$ acetonitrile $/ 0.1 \%$ trifluoroacetic acid) was added immediately and allowed to dry at room temperature. A Voyager DE-Pro model of MALDI-TOF mass spectrometer (Perseptive BioSystems, Farmingham, MA, USA) was used in positive-ion reflector mode for peptide mass fingerprinting. External calibration was performed with a standard peptide solution (Proteomix, LaserBio Labs, Sophia-Antipolis, France). Internal calibration was performed using peptides resulting from auto-digestion of porcine trypsin. Monoisotopic peptide masses were assigned and used from NCBI database 
searches with the "Mascot" and "Profound" softwares (http://www.matrixscience.com and http://prowl.rockefeller.edu).

\section{Results and discussion}

\section{1. $p H$ values}

Average $\mathrm{pH}_{45 \min }$ values were 6.69 and 6.41 for the pigs slaughtered following commercial and experimental conditions, respectively. The mean ultimate $\mathrm{pH}$ was 5.50 in both groups, as typically reported for normal pork meat.

\subsection{2-D electrophoretic protein pattern}

Up to 800 spots were detected per gel, which compares well with previous studies on muscle proteome (Gelfi, De Palma, Cerretelli, Begum, \& Wait, 2003; Lametsch \& Bendixen, 2001; Sayd, Santé-Lhoutellier, Chambon, Laville, \& Monin, 2003; Yan et al., 2001). After removal of saturated or poorly reproducible zones, 252 spots were successfully matched across the whole set of images. Fig. 1 shows the image of a silver stained gel and a computer-generated "master" gel, which contains only spots retained for further analysis. Spots that will be referred to later in the article are indicated by their unique identification number, given by PDQuest.

\subsection{Effect of postmortem storage}

Table 1 gives relative quantities of spots evolving significantly with storage time, and their identification when possible. When there was an evident discrepancy between the theoretical MW of a protein and its MW estimated through its position in the gel, it was indicated as "fragment". The two spots 6104 and 9112, identified as troponin $\mathrm{T}$, were designated as "putative fragment" since their estimated MW differed slightly from the theoretical value and they migrated slightly further in the 2 nd dimension than the troponin T spot 6103. Based on a comparable observation, spot 2101 was designated as "putative fragment" possibly originating from the strand of actin isoforms indicated on Fig. 1. Concerning spot 9112, it should be noted that its observed pI (close to 10) is very different from its theoretical pI. Furthermore, based on their identical apparent MW, it is very likely that spot 9112 corresponds to the same protein as 6104 (putative troponin $\mathrm{T}$ fragment) that did not migrate along the 1st dimension.

Intensities of 37 spots varied significantly $(p<0.05)$ with time. 10 spots were not detected at time $0 \mathrm{~h}$ but appeared postmortem, 12 increased in intensity while 15 decreased in intensity. We propose that these changes may have three different causes, namely proteolysis, post-translational changes and release from protein structures or complexes. These three phenomena are described below.

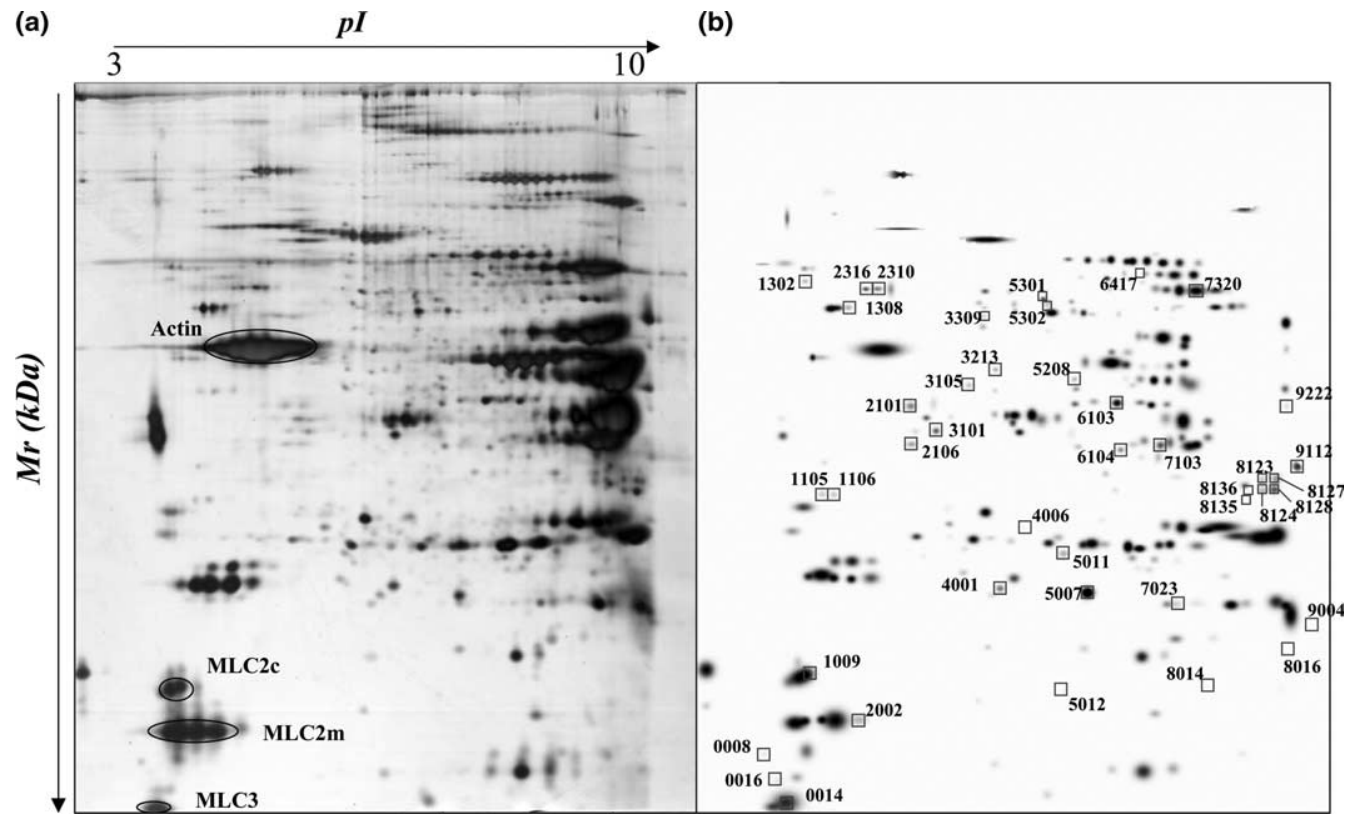

Fig. 1. Raw image of a silver-stained 2DE gel of porcine LD taken $72 \mathrm{~h}$ postmortem (a) and computer-generated master gel corresponding to all gels of samples taken at $72 \mathrm{~h}$ (b). Relative positions of Actin, MLC 2c (cardiac isoform), MLC 2m (skeletal muscle isoform) and MLC 3 were determined by comparison with results of Bouley, Chambon, and Picard (in press). 
Table 1

Quantities (arbitrary units) of spots which levels varied significantly with time

\begin{tabular}{|c|c|c|c|c|}
\hline Spot number & Identification & $0 \mathrm{~h}$ & $12 \mathrm{~h}$ & $72 \mathrm{~h}$ \\
\hline \multicolumn{5}{|l|}{ Increasing $P M$} \\
\hline 0008 & NI & 0 & 6.73 & 14.26 \\
\hline 0014 & Myosin light chain 3 & 0 & 694.26 & 979.78 \\
\hline 0016 & Myosin light chain & 0 & 6.18 & 38.11 \\
\hline 1009 & Myosin light chain 2 & 122.83 & 402.30 & 451.80 \\
\hline 1105 & Actin (fragment) & 13.86 & 32.46 & 29.26 \\
\hline 1106 & NI & 18.05 & 34 & 28.11 \\
\hline 2002 & Myosin light chain & 29.46 & 123.08 & 207.82 \\
\hline 2101 & Actin (putative fragment) & 22.88 & 48.57 & 53.68 \\
\hline 2106 & Pyr. dehydrogenase ( $\beta$-subunit) & 11.15 & 19.30 & 26.72 \\
\hline 3213 & NI & 14.38 & 20.75 & 25.68 \\
\hline 3309 & NI & 9.13 & 11.03 & 23.28 \\
\hline 4001 & Myokinase (fragment) & 0 & 27.30 & 128.08 \\
\hline 5007 & Myokinase (fragment) & 0 & 175.57 & 625.25 \\
\hline 5011 & CK (fragment) & 15.18 & 41.78 & 61.99 \\
\hline 5012 & $\alpha$-Crystallin (fragment) & 0 & 0 & 22.16 \\
\hline 5208 & NI & 13.51 & 15.32 & 23.78 \\
\hline 5302 & SR Sarcalumenin & 16.64 & 33.69 & 47.56 \\
\hline 6104 & Troponin $\mathrm{T}$ (putative fragment) & 0 & 12.48 & 24.04 \\
\hline 8014 & CK (fragment) & 0 & 0 & 12.96 \\
\hline 9004 & NI & 58.24 & 42.66 & 531.28 \\
\hline 9112 & Troponin $\mathrm{T}$ (putative fragment) & 0 & 181.63 & 384.58 \\
\hline 9222 & NI & 0 & 3.51 & 9.33 \\
\hline \multicolumn{5}{|l|}{ Decreasing $P M$} \\
\hline 2310 & ATPase $F 1$ chain $B$ & 151.43 & 93.44 & 57.74 \\
\hline 2316 & ATPase F1 chain B & 148.93 & 81.09 & 44.45 \\
\hline 5301 & $\mathrm{~T}$ complex protein 1 & 101.13 & 76.16 & 47.03 \\
\hline 6103 & Troponin $\mathrm{T}$ & 513.29 & 277.42 & 132.63 \\
\hline 6417 & NI & 39.12 & 32.23 & 0 \\
\hline 7023 & NI & 74.71 & 48.42 & 39.84 \\
\hline 7103 & Myozenin 1 & 146.74 & 140.28 & 77.37 \\
\hline 7320 & Pyruvate kinase & 434.40 & 317.63 & 227.77 \\
\hline 8016 & NI & 40.44 & 32.53 & 0 \\
\hline 8123 & Cypher 1, 2 & 106.02 & 35.15 & 30.95 \\
\hline 8124 & Cypher 2 & 155.34 & 52.99 & 41.34 \\
\hline 8127 & Cypher 1, 2 & 170.75 & 70.01 & 58.96 \\
\hline 8128 & Cypher 2 & 496.76 & 257.32 & 138.06 \\
\hline 8135 & Cypher 1,2 & 46.21 & 18.53 & 0 \\
\hline 8136 & NI & 76.44 & 76 & 0 \\
\hline
\end{tabular}

Each value is the average of six quantities.

$\mathrm{PM}$, postmortem; NI, non identified.

\subsection{Structural proteins}

As expected, several myofibrillar proteins were successfully identified among the significant spots. Thus fragments of actin and troponin T, i.e., direct results of proteolytic activity, accumulated postmortem. The latter result is most probably related with the decrease of spot 6103 corresponding to the full-length troponin $\mathrm{T}$. These results are in accordance with previous research on proteolysis during meat ageing. For example, troponin $\mathrm{T}$ has been described in various species as a proteolysis substrate (Ho, Stromer, \& Robson, 1996; Negishi, Yamamoto, \& Kuwata, 1996; Rees, Trout, \& Warner, 2003). Concerning actin, it was commonly thought until recently that it was not affected by postmortem proteolysis. However, using 2-D electrophoresis, Lametsch et al. $(2002,2003)$ showed that fragments of actin appeared during pig muscle ageing. More generally, the most frequently reported effects of proteolysis concern myofibrillar proteins situated in the I-band and that attach the Z-line either to the filaments of actin or to the sarcolemma. Thus, the degradation of the anchoring proteins titin, desmin and dystrophin has been reported on many occasions (Koohmaraie, Schollmeyer, \& Dutson, 1986; Taylor, Geesink, Thompson, Koohmaraie, \& Goll, 1995; Uytterhaegen, Claeys, \& Demeyer, 1992). Our observations bring new information related to that ultrastructural area: we observed the quantitative decrease of full-length proteins located at the Z-line, namely cypher proteins ( 1 and 2 ) and myozenin. Although it can not be formally excluded that the decrease may be due to a lesser extractability, the simplest 
explanation resides in the fact that these proteins were subject to proteolysis. Cypher proteins were first described in striated muscle by Zhou, Ruis-Lozano, Martone, and Chen (1999). They are localised at the Z-line, where they maintain its structure during muscle function by binding to its major component $\alpha$-actinin (Zhou et al., 1999, 2001). Similarly, myozenin can bind $\alpha$-actinin in the Z-line or $\gamma$-filamin at its periphery (Takada et al., 2001). The suggested proteolysis of cypher proteins and myozenin would contribute to the weakening of the Z-line observed during meat or fish ageing (Ho et al., 1996; Papa, Alvarez, Verrez-Bagnis, Fleurence, \& Benyamin, 1996), which has been correlated with the release of intact $\alpha$-actinin from bovine myofibrils during in vitro incubation with proteolytic systems (Goll, Dayto, Singh, \& Robson, 1991; Robert, Briand, Taylor, \& Briand, 1999). It contrasts with the conclusion of Taylor et al. (1995) who suggested that weakening of the Z-line was due to proteolysis of proximate proteins in the I-band but not of those of the Z-line itself.

Interestingly, the other changes affecting myofibrillar proteins were the intensity increase of four spots corresponding to myosin light chains (MLC). With the exception of spot 0016, the others were at the alkaline extremity of a strand of MLC isoforms, indicated on Fig. 1. To give an example, spot 0014 and the concomitant spot migrated as one single spot at time 0 and gradually separated into two. In other words, the intensity increase of spots 0014,1009 and 2002 is linked to a gradual shift in pI of MLC 3, 2c (cardiac isoform) and $2 \mathrm{~m}$ (skeletal muscle isoform), respectively, towards more alkaline values. In our view, as an explanation for this observation, the hypothesis of dephosphorylation deserves to be considered for several reasons. Firstly, 2-D electrophoresis allowed the separation of MLCs according to their status of phosphorylation, the less acidic spots being unphosphorylated (Bozzo, Stevens, Toniolo, Mounier, \& Reggiani, 2003). Furthermore, the natural course of events postmortem, especially the increase of sarcoplasmic $\mathrm{Ca}^{2+}$ and exhaustion of ATP reserves, would favour the accumulation of unphosphorylated forms. For example, Hidalgo, Craig, Ikebe, and Padrón (2001) reported that elevated free $\mathrm{Ca}^{2+}$ concentrations, above those required for muscle contraction, inhibited MLC phosphorylation. If free $\left[\mathrm{Ca}^{2+}\right]$ of approximately $10 \mu \mathrm{M}$ are observed during muscle contraction, they can reach $200 \mu \mathrm{M}$ in postmortem muscle (Takahashi, 1996) which would drastically inhibit MLC phosphorylation, very early postmortem. Finally, phosphorylation of MLC in vivo is regulated by an equilibrium between the activities of both MLCkinase and MLC-phosphatase (Solmyo \& Solmyo, 2003). Because ATP is required for kinase function, in contrast to phosphatase, it seems plausible that the balance between the two enzymes is jeopardised and favours dephosphorylation as soon as ATP reserves are consumed, i.e., when rigor mortis sets in. Further work should be performed to verify the hypothesis. As to spot 0016, it is well separated from other spots and was not detected at time 0: although its apparent MW is very close to its theoretical value, it may be a proteolytic fragment, which would be in accordance with Lametsch et al. (2003) who recently reported proteolysis of MLC.

\subsection{Sarcoplasmic proteins}

Several proteolytic fragments accumulated postmortem. Thus, the stress-related protein $\alpha$-crystallin is subjected to postmortem proteolysis as one fragment is clearly detected, in accordance with Sayd et al. (2003). Fragments also originated from the metabolic proteins myokinase and creatine kinase, thereby confirming the degradation of these proteins involved in energy metabolism (Lametsch et al., 2002; Stoeva, Byrne, Mullen, Troy, \& Voelter, 2000). Increase in intensity of a spot corresponding to pyruvate dehydrogenase (2106) was also significant. However, since the estimated apparent MW was close to the theoretical MW for that protein, it is not possible to assess whether this is a proteolytic fragment or the full-length protein that would become more extractible. As to pyruvate kinase (PK), for which one isoform (spot 7320) decreased in intensity with time, it was previously described as a substrate of proteolysis in pig muscle (Lametsch et al., 2002). However, in the latter study, the supposedly appearing fragment had a MW of $64 \mathrm{kDa}$, i.e., higher than the reported MW for the full-length protein, reported in databases. To our knowledge, the only previous report of PK proteolysis in meat related to aged Parma ham (Sforza, Boni, Ruozi, Virgili, \& Marchelli, 2002), i.e., a product where extensive and prolonged proteolysis occurs. Our own results are not conclusive on the fate of PK during postmortem storage: although one spot of PK decreases with time, it is possible that there is a shift of this specific form towards others. The other PK spots could not be quantified successfully because of their high abundance and subsequent saturation of the spots.

Finally, it is likely that the chaperone protein T-complex protein 1 is proteolysed since its quantity decreases unambiguously without concomitant changes in neighbouring spots. Protein T-complex protein 1 has been studied in many organisms and tissues. The common function of that cytosolic chaperone protein is the folding of various newly formed or denatured proteins, essentially actin (Kubota, 2002). Tokumoto, Horiguchi, Nagahama, Ishikawa, and Tokumoto (2000) suggested that it somehow interacts with the proteasome and can be degraded by this proteolytic system. Its degradation therefore comes as no surprise during meat ageing.

Our results show that, expectedly, sarcoplasmic proteins are subjected to postmortem proteolysis. This does 
not allow us to describe the mechanisms for meat ageing. However, in future studies correlating meat quality and proteome modifications, it would be interesting to assess whether their fragments can be used as biomarkers of meat quality.

\subsection{Mitochondrial and sarcoplasmic reticulum (SR) proteins}

Two F1-ATPase chain B isoforms (spots 2310 and 2316) decreased in intensity with storage time. F1-ATPase, located in the mitochondrial matrix, is a subunit of a mitochondrial enzymatic complex. Their fast reduction in intensity suggests that they are proteolysed quite rapidly, probably after depolarisation of the mitochondria membranes. In parallel, we observed an intensity increase of a spot identified as sarcalumenin (spot 5302). Sarcalumenin is a $160 \mathrm{kDa}$ protein present in the lumen of the SR. It was shown that the gene encoding for sarcalumenin also encodes for a $53 \mathrm{kDa}$ glycoprotein protein. Both proteins co-exist and share a common activity of $\mathrm{Ca}^{2+}$ sequestration within the SR (Leberer, Timms, Campbell, \& MacLennan, 1990). The fact that the apparently full-length $53 \mathrm{kDa}$ "sarcalumenin-like" protein increases in intensity probably means that it becomes more extractible, supposedly because of disorganisation of the membrane system of SR.

\subsection{Effect of pre-slaughter conditions}

Intensities of 8 spots were significantly affected by the pre-slaughter conditions, as seen in Table 2. Out of 8 spots, 7 were consistently present in higher quantities in the group of animals transported immediately before slaughter, i.e., samples with a faster $\mathrm{pH}$ decline. The three identified spots corresponded to F1-ATPase chain $\mathrm{B}$, and to one isoform of myosin.

As previously described, F1-ATPase chain B was proteolysed in both groups. However, the full-length protein was initially over-expressed in the group of an- imals with a higher rate of $\mathrm{pH}$ drop. It remains unclear whether the difference reflects individual variations in the expression of mitochondrial ATP-ase, or is related to the difference in muscular activity engendered by variation in pre-slaughter conditions. The literature reports increased expression of F1-ATPase after chronic increased exercise (Gonzalez, Hernando, \& Manso, 2000) but we did not find any report of short-term increase. In any case, this over-expression is most probably related to accelerated postmortem metabolism: thus, increased mitochondrial ATPase activity would contribute to enhancement of energetic pathways in order to generate protons outside of the mitochondria membranes and regenerate mitochondrial ATP levels. Furthermore, it has been shown that mitochondria, together with SR, have an important role in sequestration of excess $\mathrm{Ca}^{2+}$ from the sarcoplasm (Cheah \& Cheah, 1978) and that the process requires ATP. F1 ATP-ase synthetizes ATP under normal conditions but reverses its action and hydrolyses ATP under specific conditions such as ischemia (Bosetti, Yu, Zucchi, Ronca-Testoni, \& Solaini, 2000). Postmortem, higher amounts of ATPase would give more ATP hydrolysis, therefore less ATP would be available for $\mathrm{Ca}^{2+}$ sequestration. The consequent enhanced rise in sarcoplasm $\left[\mathrm{Ca}^{2+}\right]$ would also contribute to an acceleration of glycolysis and glycogenolysis.

The other effect of pre-slaughter conditions concerns spot 2002, which has been suggested to be a dephosphorylated form of MLC 2 (skeletal muscle isoform). The intensity of spot 2002 was drastically increased in samples from animals transported immediately before slaughter, reaching a 3-fold difference between the two groups at $72 \mathrm{~h}$ postmortem. If, as proposed above, dephosphorylation is a postmortem event related to increased sarcoplasmic $\left[\mathrm{Ca}^{2+}\right]$ and depletion of ATP, it is logical that dephosphorylated forms of MLC 2 are found in higher amounts in samples with accelerated postmortem metabolism.

In contrast, the effect of pre-slaughter conditions, and indirectly of the rate of $\mathrm{pH}$ decline, on proteolysis was

Table 2

Quantities (arbitrary units), at three postmortem sampling times, of spots whose levels varied significantly according to pre-slaughter conditions (commercial/experimental, see text)

\begin{tabular}{lllll}
\hline \multirow{2}{*}{ Spot number } & Identification & $0 \mathrm{~h}$ & $12 \mathrm{~h}$ & $72 \mathrm{~h}$ \\
\cline { 3 - 5 } & & Commercial/experimental & Commercial/experimental & Commercial/experimental \\
\hline 1302 & NI & $7.87 / 16.30$ & $13.98 / 28.78$ & $20.10 / 32.07$ \\
1308 & ATPase F1 chain B & $63.57 / 89.95$ & $52.67 / 99.70$ & $81.38 / 110.85$ \\
2002 & Myosin light chain & $29.10 / 29.82$ & $58.10 / 188.07$ & $124.53 / 291.10$ \\
2310 & ATPase F1 chain B & $120.48 / 182.37$ & $51.80 / 137.08$ & $47.57 / 67.92$ \\
3105 & NI & $0.18 / 12.00$ & $0.02 / 20.67$ & $18.55 / 21.43$ \\
4006 & NI & $16.93 / 7.70$ & $13.82 / 9.63$ & $18.90 / 7.40$ \\
6417 & NI & $26.78 / 51.45$ & $0 / 64.43$ & $0 / 0$ \\
9222 & NI & $0 / 0.25$ & $0 / 7.00$ & $0 / 18.43$ \\
\hline
\end{tabular}

Each value is the average of three quantities.

NI, non identified. 
not evident from our results. In particular, we found no statistical differences in intensities of the spots identified with certainty as proteolytic fragments. Two opposite effects of accelerating $\mathrm{pH}$ decline have been described: it can promote earlier calcium release and activation of calpains, thereby stimulating proteolysis (Dransfield, 1994). However, when the $\mathrm{pH}$ decline is exceedingly fast, it favours protein denaturation including denaturation of enzymes themselves and results in proteolysis inhibition. This is for example the case in PSE pork (Boles, Parrish, Huiatt, \& Robson, 1992; Hortos, Gil, \& Sarraga, 1994). In the present study, the difference in rate of $\mathrm{pH}$ decrease was limited ( $\approx 0.3$ units), which may have been insufficient to lead to different levels of proteolysis in the first $72 \mathrm{~h}$.

\section{Acknowledgements}

The authors acknowledge the personnel of the abattoir in Charlieu for their assistance. The authors are greatly indebted to Claudia Terlouw and Thierry Astruc for their supply of samples and their helpful guidance in discussion of the results. We also thank Michel Hébraud (INRA Theix) for his valuable contribution to the manuscript.

\section{References}

Boles, J. A., Parrish, F. C., Huiatt, T. W., \& Robson, R. M. (1992). Effect of porcine stress syndrome on the solubility and degradation of myofibrillar cytoskeletal proteins. Journal of Animal Science, 70, 454-464.

Bosetti, F., Yu, G. Y., Zucchi, R., Ronca-Testoni, S., \& Solaini, G. (2000). Myocardial ischemic preconditioning and mitochondrial F1F0-ATPase activity. Molecular and Cellular Biochemistry, 215, $31-37$

Bouley, J., Chambon, C., \& Picard, B., (in press). Mapping of bovine skeletal muscle using two-dimensional gel electrophoresis and mass spectrometry. Proteomics.

Bozzo, C., Stevens, L., Toniolo, L., Mounier, Y., \& Reggiani, C. (2003). Increased phosphorylation of myosin light chain associated with slow-to-fast transition in rat soleus. American Journal of Physiology - Cell Physiology, 285, C575-C583.

Cheah, K. S., \& Cheah, A. M. (1978). Calcium movements in skeletal muscle mitochondria of malignant hyperthermic pigs. FEBS Letters, 95, 307-310.

Dall Aaslyng, M., \& Barton Gade, P. (2000). Low stress pre-slaughter handling: Effect of lairage time on the meat quality of pork. Meat Science, 57, 87-92.

Dransfield, E. (1994). Optimisation of tenderisation, ageing and tenderness. Meat Science, 36, 105-121.

Gelfi, C., De Palma, S., Cerretelli, P., Begum, S., \& Wait, R. (2003). Two-dimensional protein map of human vastus lateralis muscle. Electrophoresis, 24, 286-295.

Goll, D. E., Dayto, W. R., Singh, I., \& Robson, R. M. (1991). Studies of the $\alpha$-actinin/actin interaction in the Z-disk by using calpain. Journal of Biological Chemistry, 266, 8501-8510.
Gonzalez, B., Hernando, R., \& Manso, R. (2000). Stress proteins of $70 \mathrm{kDa}$ in chronically exercised skeletal muscle. European Journal of Physiology, 440, 42-49.

Hidalgo, C., Craig, R., Ikebe, M., \& Padrón, R. (2001). Mechanisms of phosphorylation of the regulatory light chain of myosin from tarantula striated muscle. Journal of Muscle Research and Cell Motility, 22, 51-59.

Ho, -Y., Stromer, M. H., \& Robson, R. M. (1996). Effect of electrical stimulation on post-mortem titin, nebulin, desmin and troponin- $\mathrm{T}$ degradation and ultrastructural changes in bovine Longissimus muscle. Journal of Animal Science, 74, 1563-1575.

Hortos, M., Gil, M., \& Sarraga, C. (1994). Effect of calpain and cathepsin activities on myofibrils from porcine longissimus muscle during conditioning of normal and exudative meat. Sciences des Aliments, 9, 3-18.

Kjaesgård, I. V. H., \& Jessen, F. (2003). Proteome analysis elucidating post-mortem changes in cod (Gadus morhua) muscle proteins. Journal of Agricultural and Food Chemistry, 51, 3986-3991.

Koohmaraie, M., Schollmeyer, J. E., \& Dutson, T. R. (1986). Effect of low-calcium-requiring calcium activated factor on myofibrils under varying $\mathrm{pH}$ and temperature conditions. Journal of Food Science, $51,28-32$.

Kubota, H. (2002). Function and regulation of cytosolic molecular chaperone CCT. Vitamins and Hormones, 65, 313-331.

Lametsch, R., \& Bendixen, E. (2001). Proteome analysis applied to meat science: Characterizing postmortem changes in porcine muscle. Journal of Agricultural and Food Chemistry, 49, 43514357.

Lametsch, R., Karlsson, A., Rosenvold, K., Andersen, H. J., Roepstorff, P., \& Bendixen, E. (2003). Postmortem proteome changes of porcine muscle related to tenderness. Journal of Agricultural and Food Chemistry, 51, 6992-6997.

Lametsch, R., Roepstorff, P., \& Bendixen, E. (2002). Identification of protein degradation during postmortem storage of pig meat. Journal of Agricultural and Food Chemistry, 50, 5508-5512.

Leberer, E., Timms, B. G., Campbell, K. P., \& MacLennan, D. H. (1990). Purification, calcium binding properties and ultrastructural localization of the 53000- and 160,000 (sarcalumenin)-Dalton glycoproteins of the sarcoplasmic reticulum. Journal of Biological Chemistry, 17, 10118-10124.

Martinez, I., Solberg, C., Lauritzen, K., \& Ofstad, R. (1992). Two-dimensional electrophoretic analyses of cod (Gadus morhua $L$.) whole muscle proteins, water-soluble fraction and surimi. Effect of the addition of $\mathrm{CaCl}_{2}$ and $\mathrm{MgCl}_{2}$ during the washing procedure. Applied and Theoretical Electrophoresis, 2, 201-206.

Morzel, M., Verrez-Bagnis, V., Arendt, E. K., \& Fleurence, J. (2000). Use of two-dimensional electrophoresis to evaluate proteolysis in salmon (Salmo salar) muscle as affected by a lactic fermentation. Journal of Agricultural and Food Chemistry, 48, 239-244.

Negishi, H., Yamamoto, T., \& Kuwata, T. (1996). The origin of the $30 \mathrm{kDa}$ component appearing during postmortem ageing of bovine muscle. Meat Science, 42, 289-303.

Papa, I., Alvarez, C., Verrez-Bagnis, V., Fleurence, J., \& Benyamin, Y. (1996). Postmortem release of fish white muscle $\alpha$-actinin as a marker of disorganisation. Journal of the Science of Food and Agriculture, 72, 63-70.

Rees, M. P., Trout, G. R., \& Warner, R. D. (2003). The influence of the rate of $\mathrm{pH}$ decline on the rate of ageing for pork. I. Interaction with method of suspension. Meat Science, 65, 791-804.

Robert, N., Briand, M., Taylor, R., \& Briand, Y. (1999). The effect of proteasome on myofibrillar structures in bovine skeletal muscle. Meat Science, 51, 149-153.

Sayd, T., Santé-Lhoutellier, V., Chambon, C., Laville, E., \& Monin, G. (2003). Proteomic analysis of destructured pork muscle. In Poster. 20èmes Journées Françaises de Spectrométrie de Masse, 1619 September 2003, Toulouse, France. 
Sforza, S., Boni, M., Ruozi, R., Virgili, R., \& Marchelli, R. (2002). Identification and significance of the $\mathrm{N}$-terminal part of swine pyruvate kinase in aged Parma hams. Meat Science, 63, 57-61.

Solmyo, A. P., \& Solmyo, A. V. (2003). $\mathrm{Ca}^{2+}$ sensitivity of smooth muscle and nonmuscle myosin II modulated by $\mathrm{G}$ proteins, kinases and myosin phosphatase. Physiological Reviews, 83, 1325-1358.

Stoeva, S., Byrne, C. E., Mullen, A. M., Troy, D. J., \& Voelter, W. (2000). Isolation and identification of proteolytic fragments from TCA soluble extracts of bovine $M$. longissimus dorsi. Food Chemistry, 69, 365-370.

Takada, F., Vander Woude, D. L., Tong, -Q., Thompson, T. G., Watkins, S. C., Kunkel, L. M., \& Beggs, A. H. (2001). Myozenin: An $\alpha$-actinin and $\gamma$-filamin-binding protein of skeletal muscle Z-lines. Proceedings of National Academy of Sciences of the USA, 98, 1595-1600.

Takahashi, K. (1996). Structural weakening of skeletal muscle tissue during post-mortem ageing of meat: The non-enzymatic mechanism of meat tenderization. Meat Science, 43, S67-S80.

Taylor, R. G., Geesink, G. H., Thompson, V. F., Koohmaraie, M., \& Goll, D. E. (1995). Is Z-disk degradation responsible for postmortem tenderization? Journal of Animal Science, 73, 1351-1367.

Tokumoto, M., Horiguchi, R., Nagahama, Y., Ishikawa, K., \& Tokumoto, T. (2000). Two proteins, a goldfish $20 \mathrm{~S}$ proteasome subunit and the protein interacting with $26 \mathrm{~S}$ proteasome, change in the meiotic cycle. European Journal of Biochemistry, 267, 97-103.
Uytterhaegen, L. E., Claeys, E., \& Demeyer, D. (1992). The effect of electrical stimulation on beef tenderness, protease activity and myofibrillar protein degradation. Biochimie, 74, 275-281.

Verrez-Bagnis, V., Ladrat, C., Morzel, M., Noël, J., \& Fleurence, J. (2001). Protein changes in postmortem sea bass (Dicentrarchus labrax) muscle monitored by one- and two-dimensional electrophoresis. Electrophoresis, 22, 1539-1544.

Yan, J. X., Harry, R. A., Wait, R., Welson, S. Y., Emery, P. W., Preedy, V. R., \& Dunn, M. J. (2001). Separation and identification of rat skeletal muscle proteins using two-dimensional gel electrophoresis and mass spectrometry. Proteomics, 1, 424-434.

Yan, J. X., Wait, R., Berkelman, T., Harry, R. A., Westbrook, J. A., Wheeler, C. H., \& Dunn, M. J. (2000). A modified silver staining protocol for visualization of proteins compatible with matrixassisted laser desorption/ionization and electrospray ionization mass spectrometry. Electrophoresis, 21, 3666-3672.

Zhou, Q., Chu, P. H., Huang, C. Q., Cheng, C. F., Martone, M. E., Knoll, G., Shelton, G. D., Evans, S., \& Chen, J. (2001). Ablation of cypher, a PDZ-LIM domain Z-line protein, causes a severe form of congenital myopathy. Journal of Cell Biology, 155, 605-612.

Zhou, Q., Ruis-Lozano, P., Martone, M. E., \& Chen, J. (1999). Cypher, a striated muscle-restricted PDZ and LIM domaincontaining protein, binds to alpha-actinin 2 and protein kinase C. Journal of Biological Chemistry, 247, 19807-19813. 